\title{
Substance Abuse Prevention: Perspectives from India's Addiction Treatment Professionals
}

\author{
Sebastian A Perumbilly* and Stephen A Anderson ${ }^{\dagger}$
}

\begin{abstract}
This article focused on substance abuse prevention perspectives from India. Research participants were 112 substance addiction treatment professionals associated with government approved addiction treatment centers in India. They were located in a total of 26 Indian states and 4 union territories in India. Data were collected through a survey instrument using a mixed-methods research design with a focus on concurrent strategies. Participants provided practical recommendations for creating public awareness systemically, concurrently and consistently through a prevention agenda focusing on important social sectors such as schools, employment settings, religious/spiritual settings, and at local, state and national domains of India. This study concludes that creating massive awareness campaigns simultaneously and consistently over long periods of time in all these sectors of the society will facilitate systemic change at the macro-level. Findings have practical implications for policymakers everywhere working towards preventing substance abuse.
\end{abstract}

\footnotetext{
* Assistant Professor, Marriage and Family Therapy Program, Southern Connecticut State University, New Haven, CT 06515, USA; perumbillys1@southernct.edu

† Professor Emeritus, Marriage and Family Therapy Program, University of Connecticut,, Storrs, CT 06269, USA; stephen.anderson@uconn.edu
} 
Keywords: Substance abuse prevention, Addition treatment professionals

Substance abuse and addiction are two of the largest healthcare issues confronting the world today. They cause devastating impact on abusers, their families, communities, and society. People of all ages everywhere suffer due to the harmful effects of substance abuse and addiction. For instance, according to the World Health Organization report (2014), 3.3 million people died (i.e., $5.9 \%$ of global deaths) in the year 2012 as the detrimental effects of alcohol consumption. Research studies report that babies exposed to psychoactive substances experience premature birth, underweight, and slow intellectual development; substance addicted adolescents suffer from poor academic performance, high drop-out rate, and contracting infectious diseases; addiction inflicted homes experience increased chances for child abuse, neglect and problems with the legal system (Benegal et al., 2007; Henningfield, Santora, \& Bickel, 2007; Isralowitz, 2004; Lal, 2005; NIDA, 2010; Williams, 1996).In a recent report focusing on adolescent risk factors and its adult consequences in women, it was reported that early onset of alcohol use disorders (AUD) among adolescent girls was positively associated with addiction, antisocial behavior, behavioral disinhibition, mental health problems, academic problems, deviant peer affiliation and significant health consequences for women (Foster, Hicks, Iacono\&McGue, 2014).

Substance abuse and addiction are directly linked to violence in intimate partner relationships (Crane, Oberleitner, Devine, \& Easton, 2014), elderly abuse, family disruptions, marital disharmony, parent absenteeism, problems in child development, and major deprivation in affected families (Benegal, et al 2007; Lal, 2005).Even among youth, substance use disorders increase intimate partner violence (Zaha, Helm, Baker \& Hayes, 2013). Substance abuse and addiction have been implicated in about $50 \%$ of all murders, $40 \%$ of all assaults, $35 \%$ of all rapes, and about $30 \%$ of all suicides; and in nearly half of all accidental deaths, suicides and homicides in the United States (Mohr, 1998). In a recent study with couples, it was found that partners under the influence of alcohol 
tend to demonstrate greater intimate partner aggression (Watkins, DiLillo \& Maldonado, 2015).

As a public health concern, substance abuse and addiction are directly and/or indirectly linked to the transmission of many serious infectious diseases, especially, human immunodeficiency virus infection and acquired immune deficiency syndrome (HIV/AIDS), sexually transmitted diseases (STD), hepatitis and tuberculosis. They account for $20-30 \%$ of hospital admissions and consultations, are implicated in over $20 \%$ of traumatic brain injuries, are related to $60 \%$ of all injuries reporting to emergency rooms. They are implicated in cases of self-harm, high-risk sexual behavior, tuberculosis, esophageal cancer, liver disease, and duodenal cancer (Benegal, et al, 2007; Isralowitz, 2004; NIDA, 2010; and Williams, 1996).

Reports from India indicate that substance abuse and addiction have increased in the recent years. For instance, there was a $106 \%$ nationwide increase in alcohol consumption alone, and a significant rise in the abuse of narcotics and psychoactive substances (Benegal, 2005; Bhushan, 2005; Mookerjee \& Chowdhury, 2005; Rajpal, 2005; Rajpal \& Kumar, 2005; Vaswani, 2003). Several epidemiological reports indicated that $20-30 \%$ of Indians use alcohol at harmful levels, and that $25 \%$ of current users are dependent users (Suresh-Kumar \& Thomas, 2007). Substance abuse has led to clinically significant personal impairment and debilitated people in their personal and professional roles (Benegal, et al, 2007). Venkatesan \& Suresh (2008) reported that polysubstance use (i.e.: simultaneous use of substances that belong to several categories) also rose from 10.6\% during the period of 19951996 to $20.4 \%$ during 2005-2006 in India.

Declining age of initiation of use and abuse over the past two decades is also a matter of great concern for India. For instance, data from the Indian state of Karnataka showed a drop from a mean of 28 years to 20 years between the birth cohorts of 1920-30 and 1980-90 (Benegal, 2005). India's Ministry of Welfare reported that the mean age of initiation of heroin is 14 years (Tripathi, Lal \& Kumar, 2001), and that $95 \%$ of those who abuse fall in the age group of 14-45 years. Panda et al. (2014) in a recent study done in 
the Indian state of Punjab reported that the mean age at onset of non-injected drug use was 19 years. The age group of 15-24 years emerges as a critical period for the initiation of substance abuse in India (Vaswani, 2003).

Declining age among the users is a great concern in the global community as well. When reports were compared from the World Health Organization (WHO), global deaths as a result of harmful use of alcohol alone increased from 2.5 million (WHO, 2012) to 3.3 million people(WHO, 2014); and among them were 320,000 young people between the ages of 15 and 29 (WHO, 2012).

In light of the catastrophic impact of substance abuse and addiction, nations and the global treatment community have been increasing efforts to develop substance abuse prevention programs. Though there have been many prevention studies published to date, most of them focused on adolescents as the target population (Botvin \& Griffin, 2007; Reid, et al, 2014; Vigna-Taglianti, et al, 2014), and all of them on developed countries. To our knowledge, there has been no published research study to date focusing on substance abuse prevention focusing on a developing country. Unlike previous studies, therefore, this study focused on India, a developing country, and on preventing substance abuse in the entire country, and not merely among adolescents. This study makes recommendations on how to create prevention programs simultaneously and consistently in influential systems such as schools, employment settings, religious/spiritual settings, local communities, states and nation as a whole. Creating massive awareness campaigns simultaneously and consistently over long periods of time in all these sectors of the society will facilitate systemic change at the macro-level.

When studying India's substance abuse prevention programs, we decided to focus on the perspectives of addiction treatment professionals in India. Our rationale was based on the assumption that by virtue of their interactions with patients/clients and various social systems in India, the addiction treatment professionals would be the best informed-people to talk about creating effective substance abuse prevention programs in Indian context. 
Data for this article came from our larger study focusing on India's substance addiction treatment programs from the perspectives of treatment professionals working in India (Perumbilly, 2011).This article primarily focused on the data derived from two specific questions from that study. They were:

1. What unique programs do Indian treatment centers offer/provide to promote substance abuse prevention in your community and around?

2. What needs to be done at various social levels (e.g., school systems, work settings, religious/spiritual settings, local communities, state level and national level) to prevent substance abuse?

\section{Methods}

Given the absence of any published research studies targeting treatment professionals in an Indian context, we chose a mixedmethods approach which both verified existing treatment practices and explored the rich pragmatic perspectives of Indian treatment professionals. The type of the mixed-method approach used here fell under the category of 'concurrent procedures', which refers to the collection of both quantitative and qualitative data in the same instrument at the same time in the same study (Creswell, 2014).

\section{Survey Instrument Development}

A new survey instrument that was socially appropriate and culturally relevant to India was developed specifically for this research. Several steps were followed in developing the survey instrument. First, the initial pool of items was developed based upon an extensive review of research literature. Second, the list of items was shared with clinicians and researchers working in the field both in India and in the United States. Items were reviewed for content validity and comments and suggestions for revisions were provided. Third, a pilot-test of the instrument was completed and tested. The pilot-test group was comprised of ten addiction treatment experts working in India. The group was instructed to examine the items on the instrument, to make comments 
concerning the survey directions, note any ambiguities in questions, and suggest any relevant response items that were not included in the survey. After carefully integrating comments from the pilot-test group, the survey instrument was finalized.

\section{Survey Instrument}

The 1 instrument had a total of 44 questions, which included both closed-ended and open-ended questions (Perumbilly, 2011). The closed-ended questions used Likert scales, semantic differential type scales and checklist. Open-ended questions gave the participants opportunities to gather thoughts, and answer questions using their own words. Questions 1 and 2 focused on informed-consent and eligibility-criteria of participants. Questions 3 through 10 addressed the service capability of Indian addiction treatment centers and the participants' personal perceptions on current treatment practices in India. Questions 11 through 29 focused on the participants' perspectives on the most important (desirable) treatment practices, and their rationale for recommending such practices. Questions 30 through 42 covered the respondents' demographic information, including professional training and experience. Questions 43 and 44 sought participants' interest in learning about the results from this study, and their email addresses should they wish to participate in a drawing for a laptop computer as incentive to participate in this study.

All procedures involving research participants were reviewed and approved by the appropriate Institutional Review Board (IRB). Participation in this study was voluntary.

\section{Participants}

They had to be directly engaged with providing substance abuse and addiction treatment programs in India; proficient in reading, understanding and writing in English; and capable of completing the survey instrument online. Those who did not fulfill any of these criteria were excluded from the study.

Among the 434 e-mails that were sent to treatment programs, 93 emails bounced back instantly because of incorrect e-mail addresses. 
A total of $341(74 \%)$ of all government approved substance abuse and addiction treatment centers in India were reached with this method. A total of 134 responses were received, and of these, 112 responses were useful for the data analysis. Among the 112 participants, not all of them responded to every question on the instrument. This was perfectly acceptable for us, because we had already informed the participants at the beginning of the survey instrument that they were free to skip any question they did not want to answer. In the tables below, we have given the actual number of respondents to specific questions.

\section{Procedures}

In this mixed-method focused research, both quantitative and qualitative data were used in the interpretation of the final results. Quantitative data involved computation of descriptive statistics (i.e., mean, standard deviation, and percentages). Qualitative data encompassed doing an exploratory thematic analysis from written texts from participants. In order to ensure that theme-interpretation was accurate, Indian treatment professionals, who are also cultural insiders, were consulted. To illustrate the connection between the themes and the participants, actual words of the participants are presented in tables below.

Considering the fact that this was the first descriptive study focusing on this topic, all themes from qualitative-data were included. This was to identify new directions for preventionefforts, and to help readers from other countries to browse all ideas that were presented so that they can consider the transferability of these themes in their own prevention-contexts. This is critical because all these recommendations may have the potential to make significant contributions to prevention-programs.

\section{Results}

\section{Participant Demographics}

Age. Only 90 out of 112 participants responded to the question on "age."The highest numbers of respondents belonged to the age groups between 35 and 54 years of age. 
Table 1: Age Distribution of Participants

\begin{tabular}{|c|c|}
\hline Age Group & Respondents \\
\hline \multicolumn{2}{|c|}{$(\mathbf{n = 9 0 )}$} \\
\hline $25-29$ yrs & 8 \\
\hline $30-34$ & 7 \\
\hline $35-39$ & 18 \\
\hline $40-44$ & 16 \\
\hline $45-49$ & 8 \\
\hline $50-54$ & 15 \\
\hline $55-59$ & 4 \\
\hline $60-64$ & 3 \\
\hline $65-69$ & 4 \\
\hline $70-74$ & 5 \\
\hline $75-79$ & 2 \\
\hline
\end{tabular}

Gender. Out of 112 participants, 83.03\% participants $(n=93)$ answered the question on gender, $75.3 \%(\mathrm{n}=70)$ were males, and $24.7 \% \quad(n=23)$ were females. This study did not verify if these figures are representative of the gender divide among addiction treatment professionals in India.

Education. To the question, "what was the highest degree of education you received?", only 91 participants responded. A large percentage of our research participants, as shown in Table-2, had a Master's degree, followed by those with a Bachelor's degree. It is important to note that in India, professionals with a Bachelor's degree in medicine (e.g., MBBS, BHMS, etc.) are qualified to practice medicine. A small percentage of our participants also had a Doctoral degree.

Table2: Educational Background of Participants

\begin{tabular}{|l|c|}
\hline \multicolumn{1}{|c|}{ Highest Degree of Education Respondents } & $(n=91) \%$ \\
\hline Bachelor's degree & 28.6 \\
\hline Bachelor's degree in medicine & 4.4 \\
\hline Master's degree & 48.4 \\
\hline Doctoral degree (e.g., PhD., Ed.D.,Psy.D., etc.) & 6.6 \\
\hline Doctoral degree in medicine & 5.5 \\
\hline Other & 6.6 \\
\hline
\end{tabular}


To the question, "In what academic discipline did you receive your highest degree?", 88 out of 112 participants responded. As shown in Table-3, the academic disciplines of respondents were quite varied and included such disciplines as social work, psychology, sociology, and management.

Table3: Academic Training Background

\begin{tabular}{|c|c|}
\hline $\begin{array}{l}\text { Academic disciplines in which highest degrees } \\
\text { are held }\end{array}$ & $\begin{array}{c}\text { Respondents } \\
(\mathrm{n}=88) \%\end{array}$ \\
\hline Social work & 20.5 \\
\hline Psychology & 14.8 \\
\hline Counseling & 5.7 \\
\hline Psychiatry & 2.3 \\
\hline Allopathic medicine & 5.7 \\
\hline Homeopathic medicine & 5.7 \\
\hline Ayurvedic medicine & 2.3 \\
\hline Herbal medicine & 1.1 \\
\hline Sociology & 10.2 \\
\hline Anthropology & 2.3 \\
\hline Management & 10.2 \\
\hline Theology/ Spirituality & 1.1 \\
\hline Other & 18.2 \\
\hline
\end{tabular}

Geographical locations of the participants. In light of responses $(n=92)$, participants were located in a total of 26 out of 28 Indian states and in 4 out of 7 union-territories. Further, as per this study, the majority of the research participants $(83.2 \%)$ worked in urban areas, and $16.8 \%$ in rural settings.

\section{Commonly Abused Substances in India}

Ninety nine (99) out of 112 participants responded to the question on "commonly abused substances" in their community. Table- 4 clearly outlines the commonly abused substances used in India between urban and rural settings in order of their prevalence. Alcohol, nicotine and marijuana were the most commonly abused substances both in urban and rural settings. 
Table4: Commonly Abused Substances in India

\begin{tabular}{|l|c|c|}
\hline \multicolumn{1}{|c|}{ Substance } & $\begin{array}{c}\text { Urban }(n=83) \\
\text { M (SD) }\end{array}$ & $\begin{array}{c}\text { Rural }(n=16) \\
\text { M (SD) }\end{array}$ \\
\hline Alcohol & $4.79(.72)$ & $5.0(.0)$ \\
\hline Nicotine & $4.79(.67)$ & $5.0(.0)$ \\
\hline Marijuana & $4.37(.87)$ & $4.45(.82)$ \\
\hline Prescription medications: Opioids & $3.98(.99)$ & $2.45(2.16)$ \\
\hline $\begin{array}{l}\text { Prescription medications: CNS } \\
\text { depressants }\end{array}$ & $3.95(1.06)$ & $2.09(2.07)$ \\
\hline Inhalants & $3.89(1.25)$ & $1.63(1.96)$ \\
\hline Heroin & $3.41(1.21)$ & $2.45(2.16)$ \\
\hline Cocaine & $2.83(1.12)$ & $1.81(1.67)$ \\
\hline Prescription medications: Stimulants & $2.9(1.15)$ & $.90(1.37)$ \\
\hline Steroids & $2.55(1.48)$ & $1.36(2.01)$ \\
\hline Methamphetamine & $2.3(1.08)$ & $1.0(.0)$ \\
\hline Club drugs & $2.28(1.22)$ & $.72(1.0)$ \\
\hline Acid & $1.77(1.0)$ & $.36(.50)$ \\
\hline
\end{tabular}

\section{Common Strategies Used for Promoting Prevention Programs}

To the question "In your professional opinion, what unique programs do Indian treatment centers offer/provide to promote substance abuse prevention in your community and around?", 99 out of 112 responded. According to their responses, outreach to increase awareness among the general public was the most common; and, conducting psycho educational camps and collaborating with spiritual and religious leaders were unique features of these prevention programs. See Table 5below for other strategies used as part of promoting prevention programs both in urban and rural communities in India. The three features that stand out for Indian treatment programs are: that prevention efforts are carried out as an integral part of the mission of India's addiction treatment programs; that treatment professionals carry out both treatment interventions and prevention programs; and prevention efforts are consistently reflected both in urban and rural settings throughout India. These features are unique to India, because nowhere in the world, to our knowledge, has these been practiced consistently throughout as in India. 
Table 5: Strategies for Promoting Prevention Programs

\begin{tabular}{|l|c|c|}
\hline \multicolumn{1}{|c|}{ Prevention Features } & $\begin{array}{c}\text { Urban } \\
\text { (n=83) \% }\end{array}$ & $\begin{array}{c}\text { Rural } \\
\text { (n=16) \% }\end{array}$ \\
\hline $\begin{array}{l}\text { Outreach awareness programs for public (In } \\
\text { corporate, factories, schools) }\end{array}$ & 96.4 & 100.0 \\
\hline $\begin{array}{l}\text { Information dissemination during } \\
\text { community gatherings(Handouts/ fliers at } \\
\text { festivals and celebrations) }\end{array}$ & 97.6 & 93.8 \\
\hline $\begin{array}{l}\text { Educating community leaders and } \\
\text { professionals (To help understand and } \\
\text { identify addiction) }\end{array}$ & 91.6 & 93.8 \\
\hline $\begin{array}{l}\text { Mobile educational programs (Awareness } \\
\text { creating in underprivileged areas) }\end{array}$ & 89.2 & 81.3 \\
\hline $\begin{array}{l}\text { Conducting psycho educational camps on } \\
\text { addiction(Led by medical team and } \\
\text { clinicians) }\end{array}$ & 86.7 & 100.0 \\
\hline $\begin{array}{l}\text { Collaborating with spiritual and religious } \\
\text { leaders (To discuss prevention issues) }\end{array}$ & 74.7 & 81.3 \\
\hline $\begin{array}{l}\text { Counseling for street children(A group most } \\
\text { vulnerable to addiction) }\end{array}$ & 48.2 & 68.8 \\
\hline $\begin{array}{l}\text { Bringing celebrities to promote awareness } \\
\text { programs }\end{array}$ & 26.5 & 6.3 \\
\hline
\end{tabular}

\section{Creating Public Awareness in Important Social Sectors}

In response to the question, "In your professional opinion, what needs to be done at various social levels (e.g., school systems, work settings, religious settings, local communities, state level and national level) to prevent substance abuse?",Eighty four percent $(84 \%)$ of participants offered several recommendations /suggestions. All those suggestions were summed up as a single central theme: creating public awareness at various social sectors such as school settings, employment settings, religious/spiritual settings, local communities and state and national settings. In the following pages, we will look at each of these social sectors.

Creating public awareness in school settings. Eighty four percent (84\%) of participants emphasized the critical role of starting prevention 
education in school systems, and some quotes as shown below capture their rationale:

"...root of the [substance] problems start from school."

"Awareness programs should start in school. Children should know the facts about addiction. Once the awareness comes based on facts, then the decision to change comes from within."

"Students can bring this information to their parents, families and villages."

"...children can change their families more effectively....

Children can bring their addicted parents into treatment. Children can be the most powerful team member in treatment."

Based on qualitative data, three subthemes emerged: mandatory inclusion of prevention education in school curriculum; creative use of educational formats to engage students; and training of school teachers as advocates for prevention awareness. Subthemes and significant participant-quotes are presented in table- 6 .

Table 6: Creating-Awareness-Programs in School Settings

\begin{tabular}{|l|l|l|}
\hline \multicolumn{1}{|c|}{ Subthemes } & \multicolumn{1}{|c|}{$\begin{array}{c}\text { (n=94) } \\
\mathbf{8 4} \%\end{array}$} & \multicolumn{1}{c|}{ Participant Quotes } \\
\hline $\begin{array}{l}\text { Mandatory } \\
\text { inclusion of } \\
\text { prevention } \\
\text { education in } \\
\text { school curriculum }\end{array}$ & & $\begin{array}{l}\text { "We need to focus early on in schools, and } \\
\text { addiction awareness programs should be made } \\
\text { mandatory requirement of school education." }\end{array}$ \\
& $\begin{array}{l}\text { "Integrate more educational programs/ } \\
\text { prevention programs in the school curriculum. } \\
\text { Prevention related information should be kept } \\
\text { consistently in the school curriculum. If the } \\
\text { awareness programs are conducted only once a } \\
\text { year, it may not have much impact." }\end{array}$ \\
\hline
\end{tabular}




\begin{tabular}{|c|c|c|}
\hline Subthemes & $\begin{array}{c}(n=94) \\
84 \%\end{array}$ & Participant Quotes \\
\hline $\begin{array}{l}\text { Creative use of } \\
\text { educational } \\
\text { formats to engage } \\
\text { students }\end{array}$ & & $\begin{array}{l}\text { "More awareness and prevention programs } \\
\text { should be done in school system; more video } \\
\text { and talks to be given to increase awareness, } \\
\text { especially about new kinds of drugs." } \\
\text { "Prevention Programmes through skits, } \\
\text { personal testimonies, display and distribution } \\
\text { of Information Educational Communication } \\
\text { (IEC) Materials." } \\
\text { "School children visiting hospitals where these } \\
\text { patients are admitted." }\end{array}$ \\
\hline $\begin{array}{l}\text { Training school } \\
\text { teachers to be } \\
\text { advocates of } \\
\text { prevention } \\
\text { awareness in } \\
\text { school settings }\end{array}$ & & $\begin{array}{l}\text { "Teachers should be educated in providing } \\
\text { prevention related education." } \\
\text { "Training teachers to educate children } \\
\text { throughout the academic programs." } \\
\text { "Teachers need training; more supplies on } \\
\text { teaching aids on substance abuse and } \\
\text { addiction." }\end{array}$ \\
\hline
\end{tabular}

Creating-public-awareness in employment settings. Fifty percent (50\%) of respondents offered various practical recommendations for creating-public-awareness to prevent substance abuse in work settings. Six subthemes emerged from their recommendations, and they are: organizing seminars and workshops to create awareness in work settings; establishing employee assistance programs; educating supervisory staff; establishing treatment support groups; maintaining treatment-friendly approach; and establishing centers for relaxation. Themes and participant quotes are presented in Table-7. 
Table7: Creating-Awareness-Programs in Work Settings: Participant Suggestions

\begin{tabular}{|c|c|c|}
\hline Subthemes & $\begin{array}{c}(\mathrm{n}=56) \\
50 \%\end{array}$ & Participant Quotes \\
\hline $\begin{array}{l}\text { Organizing } \\
\text { seminars and } \\
\text { workshops to } \\
\text { create } \\
\text { awareness }\end{array}$ & & $\begin{array}{l}\text { "[Present] prevention programmes through skits, } \\
\text { personal testimonies, display and distribution of } \\
\text { Information Educational Communication (IEC) } \\
\text { materials." } \\
\text { "Awareness programs and skills for resisting } \\
\text { alcohol should be taught." } \\
\text { "[Organize] periodic medical camps and awareness } \\
\text { programmes." } \\
\text { "Stress management programs should be taught } \\
\text {..." } \\
\text { "More awareness programmes among employees; } \\
\text { substance use should be seen as health/welfare issue } \\
\text { rather than a disciplinary issue." }\end{array}$ \\
\hline $\begin{array}{l}\text { Establishing } \\
\text { employee } \\
\text { assistance } \\
\text { programs }\end{array}$ & & $\begin{array}{l}\text { "There should be employee assistance programs in } \\
\text { offices and factories for those who are struggling } \\
\text { with addiction." }\end{array}$ \\
\hline $\begin{array}{l}\text { Educating } \\
\text { supervisory } \\
\text { staff }\end{array}$ & & $\begin{array}{l}\text { "Proper training for supervisory staff upwards on } \\
\text { educating them on understanding the addict." }\end{array}$ \\
\hline $\begin{array}{l}\text { Establishing } \\
\text { treatment } \\
\text { support } \\
\text { groups }\end{array}$ & & "Worker support groups are needed." \\
\hline $\begin{array}{l}\text { Maintaining } \\
\text { treatment } \\
\text { friendly } \\
\text { approach }\end{array}$ & & $\begin{array}{l}\text { "Help with seeking treatment, and giving leave of } \\
\text { absence for those who are seeking treatment." } \\
\text { "Flexible policies for person who is ready to give up } \\
\text { drug abuse." }\end{array}$ \\
\hline $\begin{array}{l}\text { Establishing } \\
\text { centers for } \\
\text { relaxation }\end{array}$ & & $\begin{array}{l}\text { "Recreation Facilities." } \\
\text { "More relaxation centers, and clubs and } \\
\text { associations." }\end{array}$ \\
\hline
\end{tabular}


Creating-public-awareness in religious/spiritual settings: Forty nine percent $(49 \%)$ of respondents offered important recommendations for creating-public-awareness programs through religious/spiritual settings. Along with recommendations, they also provided critical rationale for prevention-efforts targeting religious/spiritual settings. Some participant-rationales are presented below:

"India is deeply spiritual and the religious figures have great influence in the society to work towards change."

"People tend to listen more to religious leaders than the government officials."

In light of the influence of religion, research participants made several recommendations to train religious/spiritual professionals so that they become collaborators in creating-public-awareness against substance abuse. Three critical subthemes emerged were: training and educating religious/spiritual professionals to be allies in substance abuse prevention-projects; using them as teachers; and as referral-sources for promoting treatment seeking-behavior among affected people. Subthemes and participant suggestions have been presented in Table- 8 below:

Table 8: Creating-Awareness in Religious Settings

\begin{tabular}{|c|c|c|}
\hline Subthemes & $\begin{array}{c}(n=55) \\
49 \%\end{array}$ & Participant Quotes \\
\hline $\begin{array}{l}\text { Training and } \\
\text { educating religious/ } \\
\text { spiritual } \\
\text { professionals } \\
\text { to be allies }\end{array}$ & & $\begin{array}{l}\text { "Religious leaders can be our allies if they } \\
\text { are educated in addiction related studies." } \\
\text { "Teach religious leaders on addiction } \\
\text { related subject, and they will reach out to } \\
\text { the public more effectively." }\end{array}$ \\
\hline $\begin{array}{l}\text { Using religious/ } \\
\text { spiritual } \\
\text { professionals } \\
\text { as teachers }\end{array}$ & & $\begin{array}{l}\text { "Religious leaders can be very effective in } \\
\text { educating the masses, because religion is } \\
\text { still very important in Indian culture." } \\
\text { "They need to talk about how alcoholism } \\
\text { and substance abuse destroys families. They } \\
\text { need to approach substance abuse and } \\
\text { addiction as a disease rather than a sin...." }\end{array}$ \\
\hline
\end{tabular}




\begin{tabular}{|l|c|l|}
\hline \multicolumn{1}{|c|}{ Subthemes } & $\begin{array}{c}(\mathbf{n = 5 5 )} \\
\mathbf{4 9 \%}\end{array}$ & \multicolumn{1}{|c|}{ Participant Quotes } \\
\hline $\begin{array}{l}\text { Using religious/ } \\
\text { spiritual } \\
\text { professionals } \\
\text { as referral-sources }\end{array}$ & $\begin{array}{l}\text { "Educating the religious leaders about } \\
\text { addiction programs and treatment } \\
\text { availability so that they can make referrals." }\end{array}$ \\
$\begin{array}{l}\text { "Training religious leaders to detect } \\
\text { addiction in their communities, and to make } \\
\text { referrals to the professionals." }\end{array}$ \\
\hline
\end{tabular}

Creating-public-awareness in local communities. Fifty three percent of participants offered various suggestions to create-public-awareness at the local community level. The rationale for doing so was to eradicate social stigma associated with treatment centers. The following participant-quote captured it beautifully:

"There is still social stigma attached to treatment
programs. Therefore, people don't go for treatment. To
remove the stigma, the government has to create more
educational programs in the society, and to treat the
problem from a disease perspective than from a criminal
perspective."

Three important subthemes were: educating communities through mass media; educating stakeholders in the community; and establishing task-forces to detect, to assess and to mandate treatment in communities. Subthemes and significant participantquotes are presented in Table9.

Table 9: Creating-Awareness in Local Communities

\begin{tabular}{|l|c|l|}
\hline \multicolumn{1}{|c|}{ Subthemes } & $\begin{array}{c}\mathbf{( n = 5} \\
\mathbf{9} \\
\mathbf{5 3}\end{array}$ & \multicolumn{1}{|c|}{ Participant Quotes } \\
\hline $\begin{array}{l}\text { Educating } \\
\text { communities } \\
\text { through mass media }\end{array}$ & $\begin{array}{l}\text { "Create] awareness programs through street } \\
\text { plays. This really works to educate the } \\
\text { community, and to remove stigma about } \\
\text { addiction. Community education is very } \\
\text { important to encourage addicts go for } \\
\text { treatment that is readily available in the } \\
\text { community." }\end{array}$ \\
\hline
\end{tabular}




\begin{tabular}{|c|c|c|}
\hline Subthemes & $\begin{array}{l}(n=5 \\
9) \\
53 \%\end{array}$ & Participant Quotes \\
\hline $\begin{array}{l}\text { Educating } \\
\text { communities } \\
\text { through mass media }\end{array}$ & & $\begin{array}{l}\text { "Awareness programs through street plays } \\
\text { and puppet shows. We also host TV programs } \\
\text { in the local areas, and people can call TV office, } \\
\text { and get their questions answer[ed] from a } \\
\text { panel of local experts." } \\
\text { "Since there is low literacy level, there should } \\
\text { be more pictorial teaching method...." }\end{array}$ \\
\hline $\begin{array}{l}\text { Educating } \\
\text { stakeholders }\end{array}$ & & $\begin{array}{l}\text { "Community leaders and members need to be } \\
\text { thoroughly educated about substance abuse } \\
\text { and addiction." } \\
\text { "Training local leaders and police." }\end{array}$ \\
\hline $\begin{array}{l}\text { Establishing task- } \\
\text { forces to detect, to } \\
\text { assess, and to } \\
\text { mandate treatment } \\
\text { to substance abusers } \\
\text { in the community }\end{array}$ & & $\begin{array}{l}\text { "mobilization efforts have to be built up among } \\
\text { the local communities to find out the } \\
\text { vulnerable individuals and give them } \\
\text { treatment support." } \\
\text { "More awareness is needed at the community } \\
\text { level to assess damages the substance abuse is } \\
\text { causing to the community such as violence to } \\
\text { children and women." }\end{array}$ \\
\hline
\end{tabular}

Creating-public-awareness at state and national levels. Fifty eight percent of participants (58\%) offered suggestions related to creating-public-awareness programs within states and at the national level. The subthemes emerged were: creating massive public awareness campaigns; establishing consistent national policies; consulting with treatment professionals when making national policies; enforcing stricter drug-control law; and enforcing stricter border-control to prevent drug-trafficking. Subthemes and related participant-quotes are presented in Table-10:

Table10: Creating-Awareness at State and National Levels

\begin{tabular}{|l|c|l|}
\hline \multicolumn{1}{|c|}{ Subthemes } & $\begin{array}{c}\mathbf{( n = 6 5 )} \\
\mathbf{5 8 \%}\end{array}$ & \multicolumn{1}{|c|}{ Participant Quotes } \\
\hline \hline $\begin{array}{l}\text { Creating massive } \\
\text { public awareness } \\
\text { campaigns }\end{array}$ & $\begin{array}{l}\text { "Using mass media such as television, radio, } \\
\text { can be used more effectively to create mass } \\
\text { awareness, and to lift social stigma against } \\
\text { addiction." }\end{array}$ \\
\hline
\end{tabular}




\begin{tabular}{|c|c|}
\hline & $\begin{array}{l}\text { "We need to work more with grassroots level to } \\
\text { educate families and communities." } \\
\text { "There should be more education at the slums } \\
\text { level because there is a lot of addiction there. }\end{array}$ \\
\hline $\begin{array}{l}\text { Establishing } \\
\text { consistent national } \\
\text { policies }\end{array}$ & $\begin{array}{l}\text { "India needs to have a consistent treatment and } \\
\text { prevention agenda to deal with substance abuse } \\
\text { and addiction. The country needs to have more } \\
\text { openness to understand addiction as a problem } \\
\text { beyond the individual addicts, and their } \\
\text { families. Substance abuse and addiction has to } \\
\text { be treated as a top priority at the national } \\
\text { agenda." } \\
\text { "India needs to have a more consistent } \\
\text { treatment and prevention agenda at the } \\
\text { constitutional level, so that it wouldn't change } \\
\text { with any changing political party." }\end{array}$ \\
\hline $\begin{array}{l}\text { Consulting with } \\
\text { treatment } \\
\text { professionals when } \\
\text { making national } \\
\text { policies }\end{array}$ & $\begin{array}{l}\text { "Government should listen to our [treatment] } \\
\text { professionals when they make policies on drug } \\
\text { abuse prevention and addiction treatment } \\
\text { programs in India." } \\
\text { "local [treatment] professionals are not } \\
\text { consulted when policies are formed and } \\
\text { implemented. We are told what to do, and the } \\
\text { government doesn't consult with us. We know } \\
\text { more about our local culture and our local } \\
\text { problems more than the central and local } \\
\text { governments. We should be part of the } \\
\text { consultancy team." }\end{array}$ \\
\hline $\begin{array}{l}\text { Enforcing stricter } \\
\text { drug-control law }\end{array}$ & $\begin{array}{l}\text { "More restrictions in alcohol and prescription } \\
\text { medication distribution. There should be more } \\
\text { identification card and age limit when } \\
\text { distributing alcohol and medical drugs. Now no } \\
\text { drug stores follow the law." }\end{array}$ \\
\hline $\begin{array}{l}\text { Enforcing stricter } \\
\text { border-control to } \\
\text { prevent drug- } \\
\text { trafficking }\end{array}$ & $\begin{array}{l}\text { "Drugs coming out of the border area should be } \\
\text { alerted and stopped at the borders." }\end{array}$ \\
\hline
\end{tabular}




\section{Discussion}

Unlike previous studies' foci on substance abuse prevention programs in developed countries and on specific age groups such as adolescents (Botvin \& Griffin, 2007; Reid, et al, 2014; VignaTaglianti, et al, 2014), this study is first of its kind focusing on substance abuse prevention programs in a developing country. This study emphasized the importance of creating public awareness campaigns against substance abuse for the entire population of India, a developing country, and in important social sectors such as schools, employment settings, religious/spiritual settings, local communities, state and national levels. Though each segment is unique in some ways, all of these levels are intimately interconnected within the society. Therefore, public awareness campaigns that target any segment can eventually impact society as a whole. An approach that simultaneously targets several critical sectors of society will likely bring about even larger and more rapid systemic change regarding substance abuse by coordinating consciousness-raising efforts. That is what Indian treatment professionals (i.e., research participants in this study) have advocated. Their voices are important to recognize because their perspectives are rooted in the reality of substance abuse and addiction treatment context in India.

Creating public awareness is a critical component that determines the success of any prevention effort. Prevention focused-public awareness campaigns both at the local and national level can help prevent predictable problems, protect existing health, and promote desired potentials in human society (Bloom, 1996 \& 2000).Several studies have confirmed the effectiveness of awareness campaigns in raising community's awareness against substance abuse, motivating people to participate in prevention efforts, contributing towards encouraging clients to seek help, reducing use of psychoactive substances, and thus preventing new cases of abuse and addiction (Barrett \& de Palo, 1999; Stephens-Hernandez, et al, 2007).Indian treatment professionals confirmed the previous studies and highlighted the importance of creating-publicawareness at various societal systems concurrently as a necessary component of substance abuse prevention efforts. 
Consistent and well-organized public awareness campaigns have the capacity to remove discrepancies in views related to what addiction is in societies. For instance, in the United States, substance addiction is broadly looked at from two competing perspectives: as a behavioral problem which requires legal remedy with the involvement of police and court system; and as a treatable disease as proposed by mental health and medical community (DiClemente, 2003). Often these discrepancies that exist among related social systems within the same society can project confusing messages, and get professionals and social agencies into competing positions in the same society. As against this background, Indian participants' proposals to create a coordinated countrywide public awareness campaign in all major social sectors, as led by multidisciplinary teams of treatment professionals, will go a long way in bringing consensus among competing views related to addiction in the society. Further, such a coordinated awareness campaign can bring about a macro-systemic change that will educate, dispel myths and fears associated with addiction in families and communities, eradicate/remove stigma which alienates people from each other and from seeking treatment, and encourage people to seek treatment without being afraid of social stigma.

Prevention messages need to be drawn from ecologically grounded perspectives and delivered in authentic ways from relatable and credible sources (Reid, et al. 2014). Indian treatment professionals were able to identify what these authentic sources were in their socio-cultural settings, namely school settings and religious/spiritual settings.

Change is most likely to occur if the source of the message is perceived as reliable and caring to those affected by substance abuse and addiction. In India, school teachers and religious professionals traditionally have been viewed as critical sources of care and formation. Therefore, if teachers and religious/spiritual professionals are equipped with accurate health promotion related information, their messages are likely to be perceived as credible. Stakeholders and community leaders can also be actively involved in the process of prevention education to communicate consistent message against substance abuse. 


\section{Limitation}

Exploration of the topic of prevention of substance abuse and addition in India was limited to a subgroup of treatment providers. The inclusion-exclusion criteria for this research were limited because only those who were proficient in English and capable of completing the survey instrument online were included. However, the strength of the study sample was that in India, prevention programs are generally carried out by the same professionals who provide substance abuse treatment. Thus, they are the most knowledgeable and they consistently operate in both urban and rural settings throughout India.

\section{Conclusion}

This study emphasizes the importance of integrating prevention efforts in every segment of the society. Indian treatment professionals identified key stakeholders in the society and recommended ways to prepare them to embrace the prevention efforts to reach out to everyone in the nation. Future researchers will investigate and articulate optimal ways to engage the entire society in future substance abuse prevention efforts.

\section{References}

Barrett, M. E., \& de Palo, M. (1999). Community-based intervention to reduce demand for drugs in Northern Thai tribal villages. Substance Use E Misuse, 34, 1837-1879.

Benegal, V. (2005). India: alcohol and public health. Addiction, 100, 1051-1054.

Benegal, V., Bajpai, A., Basu, D., Bohra, N., Chatterji, S., Galgali, R.B., et al. (2007). Proposal to the Indian Psychiatric Society for adopting a specialty section on addiction medicine (alcohol \& other substances).Indian Journal of Psychiatry, 46, 277-282.

Bhushan, R. (2005). Drug de-addiction programmes in India. In R. Lal (Ed.) Substance use disorder: manual for physicians (pp. 1-3). New Delhi: National Drug Dependence Treatment Centre, All India Institute of Medical Sciences. 
Bloom, M. (1996). Frame of reference for primary prevention practice. In M. Bloom, Primary prevention practices (pp. 1-23). Thousand Oaks, CA: Sage Publications.

Bloom, M. (2000). Twenty years of the journal of primary prevention: a collage. Journal of Primary Prevention, 20, 189-255

Botvin, G. J., \& Griffin, K.W. (2007). School-based programs to prevent alcohol, tobacco and other drug use. International Review of Psychiatry, 19, 607-615.

Crane, C.A., Oberleitner, L.M.S., Devine, S., \& Easton, C.J. (2014). Substance use disorders and intimate partner violence perpetration among male and female offenders. Psychology of Violence, 4, 322-333.

Creswell, J.W. (2014). Research design: qualitative, quantitative, and mixed methods approaches (4thed.). Thousand Oaks, CA: Sage Publications.

DiClemente, C.C. (2003). Addiction and change: how addictions develop and addicted people recover. New York: Guilford Press.

Foster, K.T., Hicks, B.M., Iacono, W.G., \&McGue, M. (2014). Alcohol use disorder in women: risks and consequences of an adolescent onset and persistent course. Psychology of Addictive Behaviors, 28, 322-335.

Henningfield, J.E., Santora, P.B., \& Bickel, W.K. (2007). Preface. In J.E. Henningfield, P.B. Santora, \& W.K. Bickel (Eds.).Addiction treatment: science and policy for the twenty-first century (pp.xiiixvii). Baltimore: The Johns Hopkins University Press.

Isralowitz, R. (2004). Drug Use, a reference handbook: Contemporary world issues. Santa Barbara, CA: ABC Clio.

Lal, R. (Ed.). (2005). Substance use disorder: manual for physicians. New Delhi: National Drug Dependence Treatment Centre, All India Institute of Medical Sciences.

Mohr, A.F. (1998). Adolescent substance abuse: vulnerability and protective factors from a developmental perspective (Unpublished doctoral dissertation). University of Calgary, Calgary, Canada.

Mookherjee, H.N., \& Chowdhury, S.K. (2005). Drug abuse among young adults in Calcutta, India. Journal of Alcohol $\mathcal{E}$ Drug Education, 49, 19-22.

NIDA Info Facts (2010). Retrieved from http:// www.nida.nih.gov/PDF/InfoFacts/TreatmentStats.pdf 
Panda, S., Roy, T., Pahari, S., Mehraa, J., Sharma, N., Singh, G., Singh, J., Joseph, F., Singh, S., \& Sharma, N.M. (2014). Alarming epidemics of human immunodeficiency virus and hepatitis $C$ virus among injection drug users in the northwestern bordering state of Punjab, India: prevalence and correlates. International journal of STD EAids, 25, 596-606.

Perumbilly, S.A. (2011). Substance abuse and addiction treatment programs in India: exploring the voices of Indian treatment and research professionals (Doctoral dissertation, University of Connecticut, CT, USA). Retrieved from http://0search.proquest.com.www.consuls.org/pqdtft/docview/90951 2520/fulltextPDF/A89863CEF04B4682PQ/1?accountid=13743

Rajpal, H.,\& Kumar, A. (2005). Epidemiology of substance use. In R. Lal (Ed.) Substance use disorder: manual for physicians (pp. 114). New Delhi: National Drug Dependence Treatment Centre, All India Institute of Medical Sciences.

Rajpal, H. (2005). Prevention of substance abuse: the Indian experience. World Psychiatry, 4, 35.

Reid, R.J., Garcia-Reid, P., Forenza, B., Eckert, C., Carrier, M.,\& Drag, S. (2014). Let our voices be heard: urban minority adolescents share their perspectives regarding substance abuse and HIV/AIDS prevention messages. American Journal of Health Promotion, 29(2), 107-114.

Stephens-Hernandez, A.B., Livingston, J.N., Dacons-Brock, K., Craft, H.L., Cameron, A., Franklin, S.O., \& Howlett, A.C. (2007).Drama-based education to motivate participation in substance abuse prevention. Substance Abuse Treatment, Prevention and Policy,2, 1-11.

Suresh-Kumar, P.N., \& Thomas, B. (2007). Family intervention therapy in alcohol dependence syndrome: one year follow up study. Indian Journal of Psychiatry, 49, 200-204.

Tripathi, B.M., Lal, R., \& Kumar, N. (2001). Substance abuse in children and adolescents: an overview. Journal of Personality and Clinical Studies, 17, 67-74.

Vaswani, M. (2003). Emerging trend of drug abuse patterns in India: the role of urine testing. Addictive Disorders $\mathcal{E}$ Their Treatment, 2, 79-83. 
Venkatesan, J., \& Suresh, S. (2008). Substance dependence: decades apart in a teaching hospital. Indian Journal of Psychiatry, 50, 100105.

Vigna-Taglianti, F.D., Galanti, M.R., Burkhart, G., Caria, M.P., Vadrucci, S., \& Faggiano, F. (2014). Unplugged, a European school-based program for substance use prevention among adolescents: overview of results from the EU-Dap trial. New Directions for Youth Development, 141, 67-82.

Watkins, L.E., DiLillo, D., \& Maldonado, R.C. (2015). The interactive effects of emotion regulation and alcohol intoxication on lab-based intimate partner aggression. Psychology of Addictive Behaviors. Advance online publication. http:// dx.doi.org/10.1037/adb0000074

Williams, T.G. (1996). Substance abuse and addictive personality disorders. In F. Kaslow (Ed.), Handbook of relational diagnosis and dysfunctional family patterns (pp. 448-462). New York, NY: John Wiley \& Sons, Inc.

World Health Organization(2012).Management of substance abuse: facts and figures. Retrieved from http://www.who.int/substance_abuse/facts/en/index.html

World Health Organization (2014). Management of substance abuse: alcohol. Retrieved from http://www.who.int/substance_abuse/facts/alcohol/en/ Zaha, R., Helm, S., Baker, C., \& Hayes, D. Intimate partner violence and substance use among Hawaii youth: an analysis of recent data from the Hawaii youth risk behavior survey. Substance Use $\mathcal{E}$ Misuse, 48, 11-20. 